\title{
Tourism policy and environmental impacts in Musina municipality: lessons from a case study of failure
}

\author{
Azwindini Isaac Ramaano \\ Department of Geography and Geo-Information Sciences, University of Venda, \\ Thohoyandou, South Africa
}

Received 2 December 2020 Revised 18 December 2020 11 January 2021 Accepted 14 January 2021

\begin{abstract}
Purpose - Musina municipality is one of the driest regions in Limpopo Province, South Africa. It is, like many rural communities within the country, a low-income area. Nonetheless, being embedded within the tourism-orientated landscape of the Vhembe district in Limpopo, it possesses the potential for communitybased tourism. This study aims to review the perception and application of tourism development policy in the Municipality using primary and secondary data. The study discovered poor enforcement of tourism development policy paired with a substandard knowledge of sustainable and responsible tourism principles. Consequently, the negative environmental impacts of tourism activities had exacerbated. The study recommends a need for improved policy implementation and strategies to advance local communities' livelihoods while also managing natural resources.
\end{abstract}

Keywords Tourism, Livelihoods, Sustainable tourism, Responsible tourism, Sustainability, Environmental tourism impact, Tourism development policy

Paper type Research paper

\section{Introduction}

Ensuring a comprehensive use of communal land (e.g. for tourism investment) could be an integral element of wealth creation in rural areas (Ramaano, 2019). In South Africa, legislation directed at a significant redistribution of land, restitution of land rights and the consolidation of current landowners' rights (Restitution of Land Rights Act 22 of 1994; South Africa, 1996) has been undertaken. Thus, the Environment Conservation Act provides for the effective protection and controlled utilization of the environment (ECA 73 OF 1989 amended by 50 of 2004). Additionally, South Africa is considered as one of the 17 mega diversity countries (nations that collectively account for $70 \%$ of global biodiversity), which factor implies its tourism potential (Crouch, 2008). The National Environmental Management Biodiversity Act provides for the management and protection of the country's biodiversity within the framework established by NEMA (National Environmental Management Act). That Act provides for the protection of species and ecosystems, the

(C) Azwindini Isaac Ramaano. Published in Tourism Critiques: Practice and Theory. Published by Emerald Publishing Limited. This article is published under the Creative Commons Attribution (CC BY 4.0) licence. Anyone may reproduce, distribute, translate and create derivative works of this article (for both commercial and non-commercial purposes), subject to full attribution to the original publication and authors. The full terms of this licence may be seen at http://creativecommons.org/ licences/by/4.0/legalcode

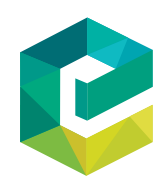

Tourism Critiques: Practice and Theory Vol. 2 No. 1, 2021 pp. $91-114$ 
TRC

2,1

92

sustainable use of indigenous biological resources, equity in bio-prospecting and the establishment of a regulatory body on biodiversity (South Africa biodiversity institute) (NEMBA 10 of 2004).

Also, the Limpopo Government enacted the Limpopo Environmental Management Act in 2003 to provide for the declaration and management of provincial protected areas (Glazewski, 2005). Subsequently, the Limpopo Tourism Agency (LTA) was established under the Limpopo Tourism (Act 2 of 2009) to promote and advance tourism within the Province. The agency defines ecotourism as responsible travel to the natural areas that conserves the environment and improves the well-being of local people (Keyser, 2002). While the terms ecotourism and sustainable tourism can be used interchangeably, both advocate for environmental, economic and societal efficiency. In many rural areas such as Musina Municipality, ecotourism is among the more common form of tourism practices (Ramaano, 2019). However, to achieve its aims there is a need for tourism investment that empowers marginalized and previously disadvantaged individuals (PDIs). The Musina municipality's rural communities are in dire need of such investments for their socio-economic improvement and sustainability achievements (South Africa, 1996; Kirsten and Rogerson, 2002; Ramaano, 2019). However, there are mixed feelings by the private sector regarding tourism investment in South Africa's rural communities due to complicated issues of land ownership, poor infrastructure and lack of a tourism market (Kirsten and Rogerson, 2002). Dieke (1993) investigated tourism development complicating issues in The Gambia and in 2003 evaluated the nature of tourism development policy and its associated challenges. Dieke (1993) urged on native people skills development to elevate their employment scale in the tourism industry. Hence, he contended for indigenized labor in tourism undertakings in The Gambia and Africa. Similarly, Nanthakumar et al. (2007) reminded us that tourism development policy plays an integral role in promoting and enhancing trade operation and economic development within the tourism industry.

Akin to the African scenarios, De Araujo and Dredge (2012) and Lohmann and Dredge (2012) reviewed the origin of central tourism policies in Brazil, beginning from the 1990s when Brazil commenced its tourism development policy and planning. They compared those policies to the extensive image changes then occurring within the tourism industry, asserting that tourism had become the main determinant of Brazilian economic growth and community development. They found that new policies and advances, improved knowledge and investment in tourism have contributed to a substantial shift in tourism enterprises, destination development and community participation. Moreover, they further maintained that Brazil with its abundant cultural and natural charms, like other developing countries such as South Africa, still had to battle to sustain an extension of infrastructure, product development and approachability, the character of services, market access and employee training. Thus, they emphasized the significance of development matters such as the transformation of policy circumstances, community benefit tourism and indigenous tourism. Moreover, Ekanyake and Long (2012) probed links between tourism development and economic growth in developing countries using mixed panel co-integration methods. As such, Jones (1993) maintained that if not properly planned and maintained, tourism can damage significant and fragile parts of the natural environment. Again, in another study, White et al. (2006) appraised the need to adopt sustainable development when dealing with major global industries, including tourism (See also Figure 1 below). Given such findings, the concept of sustainable tourism forms the basis of this study (See also Figure 2 below). However, while carefully planned tourism development can render social, cultural and environmental benefits, the opposite is often a reality with tourism development policy enforcement lacking on the part of the authorities, local communities and tourists. To 


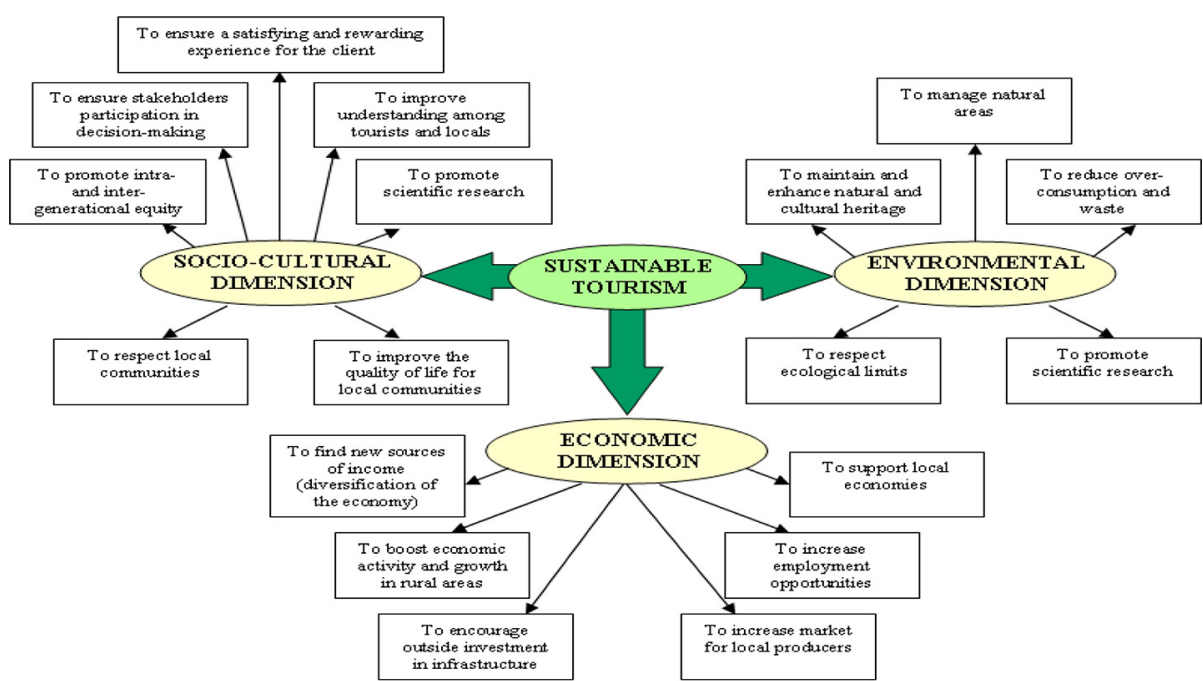

Source: White et al. (2006), Zamfir et al. (2017), Ramaano (2019)
Tourism

policy

Figure 1.

Principles of sustainable tourism

counter such failings, Joshi and Dhyani (2009) demonstrated how the introduction of environmental fees positively contributed to the environmental sustainability of tourism in the sensitive environment of Sikkim Himalaya.

Biological resource observation organizations are found in many countries and often engage local communities. It has been proposed that such organizations empower local people while encouraging conservation (De Araujo Lima Constantino et al., 2012). Moreover, Martín et al. (2014) noted the significance and influences of seasonal shifts of tourists within sensitive environments and highlighted the ability of tourists and local management to maintain environmental sustainability during such periods of peak visitation. Such a realization has also been paralleled by the growth in the number of worldwide organizations that concentrate on sustainable tourism and ecotourism activities. For example, National Geographic Expeditions, which emanated in the USA, has rendered eco-expeditions for adventurous tourists. The expeditions support responsible tourism explorations and provide data for research agencies (National Geographic Expeditions, 2015). In South Africa, there are tour operators such as "Baobab Travel," which was formally established in the UK. In South Africa, the company offers responsible and sustainable ecotourism packages (Baobab Travel, 2015). The latter could prove to be an essential milestone for newer tourism ventures and activities in Musina municipality such as the "Big Tree Nature Reserve" (Baobab tree). At the Reserve, an apparent lack of conservation policies and unmonitored tourism activities seems to be the evident problem preventing its proper preservation against visitor abuse (Figure 3). The latter is also visible through the fragmented resources within the reserve itself (See Figure 4 and Figure 3 below). McIntyre $e t$ al. (1993) indicated that communities should maintain themselves at all levels (national, provincial and local) to better identify development goals and link with government and role-players at all layers. Thus, they have to be able to spell out existing and possible tourism activities and attractions within the respective local communities and encourage by all means sustainable 


\section{TRC}

2,1

94

Figure 2.

The envisaged model of a sustainable tourism strategy for the study and the communities in Musina municipality

\section{Figure 3.}

Some of the abused, scratched and painted parts of the "Big baobab tree" within the Big Tree Nature Reserve
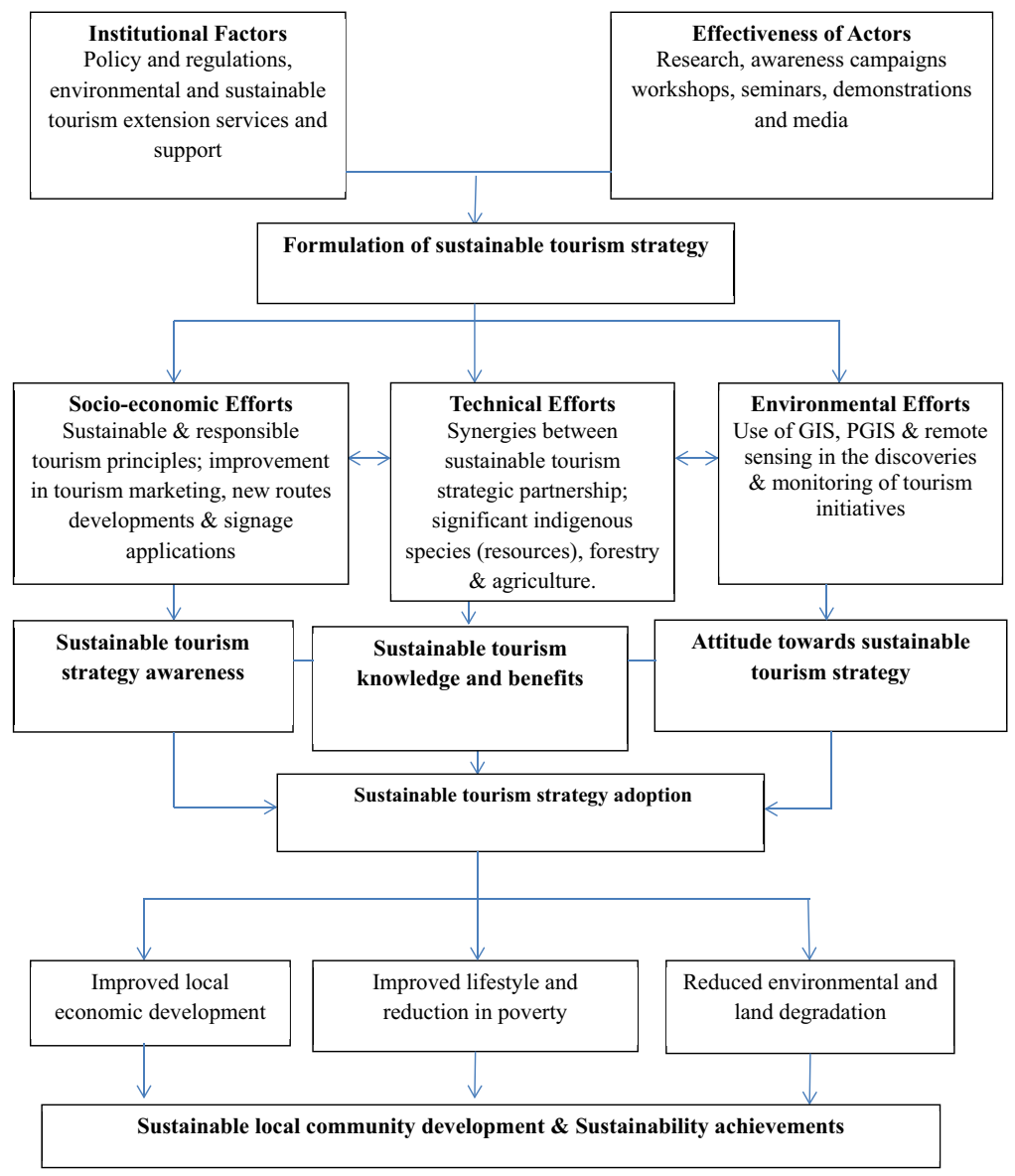

Source: Author's own Ramaano (2019)

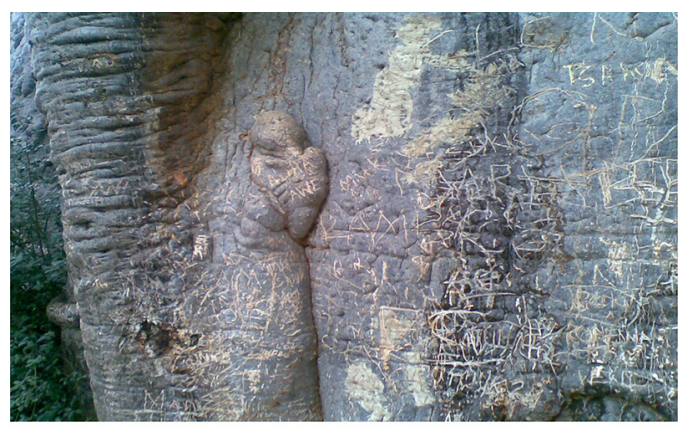

Source: Researcher, 28 March 2019 
development, as well as responsible tourism behavior. They should be interested and willing stakeholders in decision-making regarding major tourism initiatives planned and targeted for the area.

Witt and Witt (1995), Ryan and Page (2012), substantially probed the performance and significance of both the private and public sectors in tourism management. Similarly, Kepe (2004) and Ying and Zhou (2007) advised that communities should play an active major task in ensuring that desirable benefits from rural tourism are obtained. They further maintained that communities ought to join hands with non-governmental organizations (NGOs), as well as enlighten others within the community about the benefits of rural tourism initiatives and projects. However, rationality and patterns in power-sharing are significant factors in such regard (Ryan, 2002). According to Lea (1988), tourism in rural areas can generate employment, regardless of the magnitude of such opportunities and be able to aid and encourage the advancement of rural communities' livelihoods. The Musina municipality and its communities can, therefore, benefit from correctly conceived and implemented tourism policies. However, the problem statement of this research dwells on the fact that, despite the prime tourism potentials revealed by Ramaano (2019) within the study area, the local communities are seemingly failing to gain the benefits of tourism. Rather, the opposite appears to be the case, with the area suffering from both poor enforcement of tourism development policy and the negative environmental impacts of tourism. Hence, the research questions of this study are:

RQ1. To what extent does the development policy used by the Musina Local Municipality meet sustainable tourism imperatives?

$R Q 2$. How does the expert capability of the Musina municipality contribute to the environmental sustainability of tourism activities?

This study argues that, by evaluating the perception, enforcement and precision of tourism development policy alongside the potential environmental impacts of tourism, one can better advocate for the resources necessary for an integral and sustainable tourism strategy for the study area and the Municipality.

\subsection{Various forms and explanations of tourism and their significance in South Africa}

South Africa's scenic beauty, magnificent outdoors, sunny climate, cultural diversity and reputation for delivering value for money have made it one of the world's fastest-growing leisure and business travel destinations. The country is highly diverse in terms of its

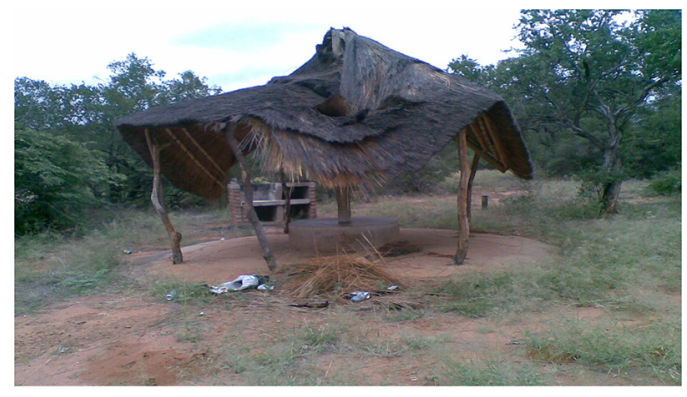

Figure 4. Destroyed "lapa" and polluted scene within the Big Tree Nature Reserve

Source: Researcher, 28 March 2019 
TRC

2,1

96

climate, culture, tourist activities and infrastructure, catering to almost every tourism niche, from business, cultural and eco-tourism, to adventure, sport and paleo-tourism (National Department of Tourism, 2012). This is no exception when it comes to the nature of the Musina municipality and its tourism assigned characteristics in Limpopo, South Africa (Ramaano, 2019). Thus, the main tourism explanations and paradigms significant within the tourism industry in South Africa are:

- Tourism and the economy; and

- developing sectors.

For example, under these classifications, "Wine tourism" has been identified as one of the quickest-growing and profitable sectors of the global tourism market (Ramaano, 2019). In 2009, wine tourism contributed an estimated R4.3bn to South Africa's tourism revenue. Wine and gourmet tourism could aid the wine industry with issues of international volatility in the demand for wine and play a major role regarding South Africa's goal of extending the geographic spread of tourism (National Department of Tourism, 2012). In the case of the Musina municipality, it might not be known for wines derived from grapes, but instead, it boasts the "Marula trees" (Sclerocarya birrea) that the locals use to produce a wine like a traditional beer called "Mukumbi." "Mukumbi" has proven to attract domestic tourists from the wider municipality. It has been suggested that the communities could bank on this tried and tested attraction and extend it to a variety of edible natural fruits and products such as locally grown watermelon and mangoes, to explore other wines and beers (Maikhuri et al., 2007; Ramaano, 2019). Such attempts might attract more tourists, especially those interested in food and Agri-tourism interests (Ramaano, 2019).

Another potential exists with medical tourism. The majority of medical tourists to South Africa come for cosmetic surgery, but the country's skilled surgeons can also offer organ transplants, cardiac, orthopedic, obesity surgery and dentistry (National Department of Tourism, 2012). Musina municipality and the study area are home to renowned traditional and spiritual healers such as the "Tshikovha" traditional healer that attracts many domestic tourists who require medical care or are simply curious within the sampled village of Tshipise (Ramaano, 2019). Spiritual healers such as "Makondeni" within the sampled village of Folovhodwe, attract several people, including those who visit frequently for church festivals and medical care. Local communities benefit from attracting visitors to such healers through retail and accommodation sales to visitors. Another dimension of medical tourism within the study area consistent with heritage and cultural tourism is the role of the elderly, traditionally the custodians of significant indigenous knowledge for the use of various plants for medicinal and other purposes. Such referred expertise has many benefits, ranging from tour guide information, indigenous knowledge preservation, intellectual property rights and innovation of new traditional medicines and increasing of beneficial bio-prospecting efforts, as well as diversification of medical tourism grounds among other benefits (Ramaano, 2019). Ryan (2005) broadly highlighted the significance of recognizing the benefits of cultural tourism within the scope of tourism development policies. As such, the traditional and indigenous knowledge of the many elderly people in the study area includes the medicinal use of species including "Aloe Vera" (Aloe barbadensis miller) alongside other plants and herbs. Such knowledge possesses an inherent value for both medical and cultural tourism. Similarly, cultural traditions in the study area can be boosted, including dances such as "Tshikona," "Malende" and "Tshigombela" which are widely practiced and can entertain tourists within the study area (Ramaano, 2019). Given these assets, a soundly based tourism development policy and its enforcement synergistically based on the traditions and 
culture of the community could well assist the economic well-being of residents. The next section presents the study area and the used methods.

\section{Study area and methods}

\subsection{Location and attributes}

Musina municipality is a branch of the Vhembe District Municipality. It is located in the furthermost North-Eastern part of the Limpopo Province, adjoining Zimbabwe in the North and Mozambique in the East through Kruger National Park. The Municipality is placed around Musina town and near to the Thulamela Municipality on the further North. It is situated between $22^{\circ} 25^{\prime} 00^{\prime \prime}$ and $22^{\circ} 50^{\prime} 00^{\prime \prime} \mathrm{E}$ lines of latitude and between $30^{\circ} 20^{\prime} 15^{\prime \prime}$ and $31^{\circ} 01^{\prime 2} 22^{\prime} \mathrm{S}$ lines of longitudes. See (Figure 5) for the location map (Musina municipality, 2019).

The overall temperature in the Musina municipal area is relatively constant and high throughout the summer of each year. The mean minimum temperature of the area is $16.1^{\circ} \mathrm{C}$ and the maximum mean is $32^{\circ} \mathrm{C}$. Davis (1995) and Ramaano (2019) note that the topographical features regulate the rainfall of the area. It can be argued that most of the dry areas commonly receive insufficient rainfall. In the Musina municipal area, its average rainfall is only $464.1 \mathrm{~mm}$ per annum. Yet the Vhembe area, including Musina, has a splendid biological diversity of flora and fauna due to its bio-geographic location and diverse topography. The district is within the greater Savanna Biome, specifically known as the Bushveld, associated with some small pockets of grassland and forest Biomes. The nature of the locale has produced a sophisticated assortment of ecological niches, respectively, occupied by a wide variety of plant and animal species (Musina Municipality, 2011; Ramaano, 2019). The area sustains the Mountain Fynbos, Sacred Forests and ancient Baobab Trees. There are wider extensive areas within Musina that are conservancies; among others, the Natural Protected areas within the Municipality include the Mapungubwe National Park (a world heritage site), Kruger National Park (Pafuri Gate in Mutale). Hence, the Musina municipality is also attached to Musina and Nwanedi nature reserves, as well as Tshipise Forever Resort (Kayamandi development services, 2007; Musina municipality,

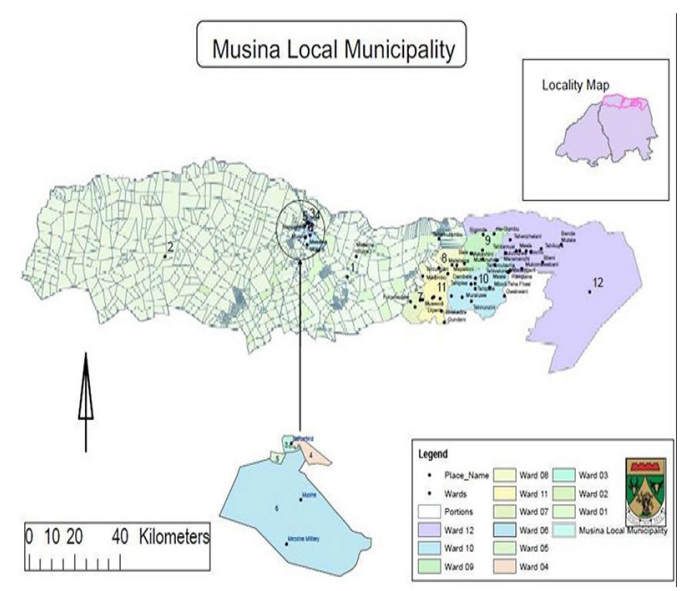

Source: Musina municipality (2019), Ramaano (2019)

Figure 5. Location of the study 
TRC

2,1

98

2011, 2019). The popular vegetation cover in Musina municipal area is the Dry Northern Mixed Savanna Bushveld type (Ramaano, 2019). The study area, thus, bears abundant tourism resources such as the Mountains of Mukununde and Dambale villages and Sagole spa in Tshipise village, Domboni Mountain caves and its cultural assets. Moreover, the Folovhodwe Tshaluwi fountain, rural campsite and human artifacts (crafts) support heritage, sustainable tourism and community-based natural resource management (CBNRM) potentials within the study area and the Municipality in general. Tourism could, therefore, also improve agroforestry and agriculture by providing secondary and spare sources of revenue for the purchase of farm implements (Ramaano, 2019). Together Agroand sustainable tourism developments can form a gestalt to improve the socioeconomic status of the local people and attain sustainability within the area.

\subsection{Data and methods}

The study reviews the perception and enforcement of tourism development policy and evaluates the environmental impacts of tourism at Musina local municipality, Limpopo, South Africa. The study used a mixed-methods design using both quantitative and qualitative surveys. In the process, ethical research procedures were observed and research permission was given by the University. Further research permissions were negotiated with tourism personnel and locals residents in the sampled villages. The study used purposive sampling and both questionnaires and interviews were adopted as principal research methods. A purposive sample is a non-probability sample based on the characteristics of a population and the objective of the study. Expert sampling is a form of purposive sampling used when research requires one to capture knowledge rooted in a particular form of expertise. It is common to use this form of purposive sampling technique in the early stages of a research process when the researcher is seeking to become better informed about the topic at hand before embarking on a later study. This form of early-stage expert-based research shapes research questions and research design (Tongco, 2007). "Therefore, the researcher applied expert sampling on the premise that a representative sample can be gained while also saving time and money" (Patton, 2001; Ramaano, 2019).

2.2.1 Sample size calculation and rationale of the study. The sample size was calculated using Taro Yamane's formula (Yamane, 1967, 1973). The given study area consists of Folovhodwe, Gumela, Tshipise and Zwigodini villages in Musina municipality that have a total population of 4,947 . Therefore, setting the sampling precision at $5 \%$ (i.e. e $=0.05$ ), the required sample size was approximately 370 . Four villages were selected, as being close to various tourism ventures and entities such as the Tshipise Forever Resort, Nwanedi Nature Reserve and Resort, Luphephe Dam, Sagole Spa (Geothermal spring), Big Tree Accommodation Lodge and the Big Tree Nature Reserve amid the rest (Tables 1 and 2).

\begin{tabular}{lcrc}
\hline Name of the villages & $\begin{array}{c}\text { Population within } \\
\text { the selected communities }\end{array}$ & $\begin{array}{c}\text { Allocation of questionnaires } \\
\text { per villages }\end{array}$ \\
\hline Folovhodwe & 2,806 & 57 & 211 \\
Gumela & 383 & 8 & 29 \\
Tshipise & 1,052 & 21 & 78 \\
Zwigodini & 706 & 14 & 52 \\
Total & 4,947 & 100 & 370
\end{tabular}

Table 1.

Villages and allocations of questionnaires in the study area

Source: Author's own (Musina municipality, 2011; Ramaano, 2019) 
Hence, (Table 1) shows the allocation of questionnaires within the selected villages in Musina municipal area, whereas (Table 2) shows the adjacent tourism ventures and entities that were interviewed in the study area. Thus, (Figure 6) shows the main road signage within the proximity to "Sagole Spa and the Big Tree Nature Reserve".

The difference between the four villages is determined by the size and proximity to the tourism ventures and entities, as well as the stakeholders and role-players involved within their management. Nwanedi Nature Reserve, Nwanedi Dam, Luphephe Dam and Nwanedi Resort occupy larger tracts of land and lie at the periphery of both Gumela and Folovhodwe villages, whereas Gumela is situated on the South gate and Folovhodwe on the North gate, respectively. Furthermore, partnerships exist between governmental agencies and commercial group entities such as Wildlife or Forever Resorts that require the involvement of local communities. However, from a different perspective concerning Tshipise and Zwigodini villages, tourism ventures and entities such as the Big Tree Nature Reserve and Sagole Spa are all in closer proximity to the local communities and have smaller tracts of land. Hence, the latter primarily relates to the engagement of both government and local communities themselves, without any semi-governmental, private sector or nongovernmental involvement and the precise details of tourism service provision remains a subject for discussions.

\begin{tabular}{llc}
\hline $\begin{array}{l}\text { Name of tourism ventures and } \\
\text { their activities }\end{array}$ & $\begin{array}{l}\text { Location of the tourism } \\
\text { venture/entity (villages) }\end{array}$ & $\begin{array}{c}\text { Key informant in-depth } \\
\text { interviews per venture/entity }\end{array}$ \\
\hline $\begin{array}{l}\text { Nwanedi nature reserve and resort, } \\
\text { (Luphephe and Nwanedi dams) }\end{array}$ & Gumela (Folovhodwe) villages & 5 \\
$\begin{array}{l}\text { The big tree holiday } \\
\text { accommodation }\end{array}$ & Zwigodini (Madifha) village & 5 \\
Manalani lodge; (Sagole spa hot & Tshipise village & 5 \\
spring) & Zwigodini (Madifha) village & 5 \\
The Big tree nature reserve (big & Zaobab and marula trees) & Zwigodini village \\
$\begin{array}{l}\text { Beria Madzonga resort } \\
\text { Musina LED and Tourism info } \\
\text { Total }\end{array}$ & Musina municipality (Musina town) & 5 \\
\end{tabular}

Source: Author's own (Musina municipality, 2011, 2019; Ramaano, 2019)

\section{$-2$}


TRC

2,1

100

The Gumela residents lament the fact that before the inception of the Reserve and its infrastructures, they were situated in more fertile land next to the river before they were relocated to make way for the preservation zone during the 1970s. Thus, communities from both the Gumela and Folovhodwe villages feel that they have been robbed of their homeland (and its better grazing for their livestock) but they receive fewer empowerments from the ventures. Nonetheless, it is known that during the initial years following the establishment of the Reserves local people had good access to employment and received subsidized wildlife meat from the Reserve every month. More recently though, such preferential treatments have been largely eroded. The Reserve used to have the big "Five" animals; all of which have since been relocated from the area. Locals also complain of poor Reserve management and rumors of elephants roaming the streets and posing danger to human lives in the adjacent communities of both Mapungubwe and Kruger national park sites within the Municipality and the Province have meant some are relieved that the big "Five" animals are no longer in their immediate vicinity. Nonetheless, the communities of Folovhodwe and Gumela villages are not completely immune from danger, as inadequate fencing in Nwanedi nature reserve still allows for the escape of Kudus that damage homesteads before being killed by the villagers for meat consumption. Also, communities still suffer the loss of their goats and chickens from wild dogs that seem to make their way out of the Reserve. Thus, in both villages, it seems conservation and tourism operations still leave much to be desired in terms of empowering the local communities, promoting sustainability and sustaining Agroand wildlife tourism enterprises (Ramaano, 2019).

Evidence suggests that the state of the infrastructures within the public and administration parts of the Reserve and the Resort is neglected and rendered unattractive by poor management, which diminishes the tourism value of the area. The communities feel that jobs are not sufficiently forthcoming from such ventures and entities. Similarly, the Tshipise village Sagole Spa, fed by its geothermal spring, has been neglected since the early 2000s and the accommodation and entertainment facilities are no longer functional. The same could be said for the Zwigodini village's "Big tree nature reserve." The Reserve has not been given much attention and monitoring, since its inception and there have been no additional tourism facilities to boost its tourism potential and capacity (Figure 4 and Figure 3).

Consequently, the "Big Tree Nature Reserve" generates few socioeconomic activities and, even worse, has meant negative environmental impacts within and around the Reserve itself. Even though Tshipise's "spring" and geological rock formations within the area retain the potential to attract tourists, enthusiasm for tourism ventures is now lacking. The lack of proper upgrading of these entities and ventures seems to cripple them even much further. Such poor enforcement of tourism development policy and the inadequate efforts to sustain environmental resources within the study area and the Municipality are increasingly evident.

This experience was evident in responses gained from both household surveys and interviews and data were extracted using primary and secondary methods as per the design of the study. Ultimately, data were collected through questionnaires, interviews, reviews of existing documents, focus group discussions and field observations. Questionnaire surveys were directed at attaining the core of the study while interviews, document reviews, focus group discussions and field surveys were significant in independently supplementing questionnaires data. The questions for the survey, interviews and focus group discussions were designed in a complementary manner and designed in a way understandable to the respondents. For example, concepts were explained within the questionnaires for the respondents to read and understand their purpose before making their responses. 
Therefore, apart from the survey $(n=370)$ (Questionnaire survey within the four sampled villages distributed between the mornings of 1 March to afternoon 30 April and collected between the mornings of 15 May to afternoon 15 June 2019), interviews $(n=30)$ (Key informant interviews within the six sampled tourism ventures and entities around the mornings and afternoons of 8/9/10 April 2019) got conducted. Focus group discussions were also undertaken in each village on approximately five interviewees at each session around the mornings and afternoons of 17/18/19/20 March 2019 (Table 3). The distances between the researcher's point of departure and the study area determined different time slots for data collections. The closer areas were interacted with during the mornings, whereas the faraway destinations were apt for afternoon slots. Also, informants and participants for interviews and focus group discussions had their specific preferable times between mornings and afternoons as per prior meetings arrangements. The focus group discussions included active members of the communities, including representatives of Civic Associations and Women Associations. Local gatherings, as well as appointments for these group discussions, were negotiated with each community and ultimately the discussions were open to anyone within the communities. Therefore, regarding such discussions, the researcher took the time to inform participants about various concepts such as sustainable tourism, ecotourism and responsible tourism; including their similarities, differences and significances, before engaging in discussions and questioning. The discussions acquired information on matters of tourism development policy, the environmental impact of tourism and sustainability in the study area. This was done in an attempt to obtain a more informed opinion about the issues. Thus, special attention was given to the participants' perceptions, experiences, opinions, feelings and knowledge on issues related to tourism development policy enforcements, environmental sustainability of tourism, livelihoods and sustainable development implications within the study area. Primary sources include original reports such as letters or eyewitness explanations of the event, whereas secondary sources included those one-step distant from primary sources and constitute an account of people who were not eyewitnesses (Esterberg, 2002; Ramaano, 2019).

Moreover, Dillon and Murphy (2008, p. 62) indicated that "secondary data refers to the recorded information rendered available by other researchers for aims other than the specific research need at hand." Consequently, secondary data were attached to previous projects and activities. For this study, the secondary data were sourced from the Musina municipality's previous IDP plan and LED strategies. The Municipality's former tourism initiatives and plans proved significant in obtaining such data (Kayamandi development services, 2007; Musina municipality, 2011, 2019). Quantitative and qualitative data analyzes were used for the study by applying Spreadsheet, Microsoft Excel, Microsoft Word Tables, cross-tabulation analysis and manual arrangements of focus group discussion.

2.2.2 Types of the required data and their purpose. Socio-demographic data were compiled from respondents and checked by reference to governmental data. Data on tourism

Villages

Folovhodwe

Gumela

Tshipise

Zwigodini

Total

Source: Author's own (Musina municipality, 2011, 2019; Ramaano, 2019)
Tourism policy

101 $-$

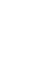


TRC

2,1

102

and development policy enforcements within the study area were also obtained from the Musina Local Municipality. The latter would generally include awareness campaigns on sustainable conservation, community-based natural resource management (CBNRM) and project funding among other related initiatives. Hence, data on sustainable and responsible tourism entailments permitted an assessment of the Municipality and local communities' commitments to sustainable and responsible tourism endeavors and also to what extent local traditional leaders and others had been involved in planning. The data included an assessment of the environmental impacts of tourism within the study area. Implicitly, the data also revealed how the technical capabilities of the Musina municipality contributed to the environmental sustainability of tourism in the study area.

\section{Results and discussions}

\subsection{The demographics of the respondents in the study area}

This results section presents information on the age and gender of respondents in the study area. Demographics are significant variables that shape any given society.

3.1.1 Gender and age profiles of the respondents. Gender and age are vital aspects of communities' households that influence basic needs such as food provisions and education qualifications. These variables were examined to better comprehend how they generally interlink and affect households' basic needs and how a precise tourism development policy can potentially and positively impact them through tourism jobs. Thus, (Figure 7) shows that of the total respondents in the survey, $(45.5 \%)$ were women and a majority of the homesteads were headed by men with 16 respondents $(54.4 \%)(n=370)$ (Questionnaire survey within the four sampled villages, distributed between the mornings of 1 March to afternoon 30 April and collected between the mornings of 15 May to afternoon 15 June 2019).

Suffice to also conceive that, as mentors and housekeepers, women can encourage tourism entrepreneurship in rural areas to prompt community development. They can actively help as entrepreneurs, travel agents, policy creators, entertainers, tour guides, game rangers, drivers, guest-house operators, managers and restaurateurs. Hence, they can develop and maintain community projects that exert desirable environmental, social and economic effects and be able to furnish and supplement their households' basic needs. It has been shown that rural women can also ensure success in pottery and craft training among other artistic opportunities (Judd, 2002; Wickens and Briedenhann, 2004; DuFour and Eaker, 2009).

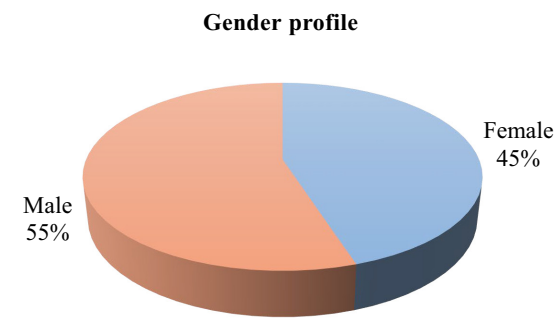

Figure 7.

Gender profile of the respondents

$$
\square \text { Female } \backsim \text { Male }
$$

Source: Author's field data, 2019 
Tourism in rural and remote settings can also offer opportunities for men and women to work together, thereby permitting households to enhance income. Equally, if women are used by the government or corporate employees it permits them to have bank accounts in their names, thereby reducing dependency on male members of the family. Tourism can also reverse the migration of male workers to urban areas or work in the mining industry, thereby alleviating women from hard labor in rural schemes with inferior access to basic amenities and infrastructure. Therefore, tourism developments that support the active participation of both men and women can reduce difficulties for those in rural settings (Wickens and Briedenhann, 2004; Ramaano, 2019).

In this study, (as shown in Figure 8), approximately $50.8 \%$ of the respondents were between 20 and 46 years of age, counteracted by an accumulative number of about $(34.7 \%)$ of the respondents between 46 and $65+$ years of age. Thus, the depictions within (Figure 8) could generally mean that the respondents are sufficiently well able-bodied and energetic members of the community, potentially fit to be actively and effectively involved in economic development, environmental conservation and sustainable tourism development endeavors should employment opportunities permit.

\subsection{Tourism development policy existence and application in the study area}

3.2.1 Respondents' responses on "having any knowledge about the existence and application of tourism or development policy in their area/village." Data in (Table 4) indicate that the majority of 358 respondents $(96.7 \%)$ responded negatively to having any knowledge about the existence and application of tourism or development policy within the study area. The other 12 respondents ( $3.2 \%$ of the sample) replied positively to the question $(n=370)$ (Questionnaire survey within the four sampled villages, distributed between the mornings of 1 March to afternoon 30 April and collected between the mornings of 15 May to afternoon 15 June 2019).

Therefore, the data indicate a significant potential failing on the part of the industry and its sponsors. An appropriate tourism development policy would advantageously mingle with environmental and conservation principles in guiding sustainable usage of both

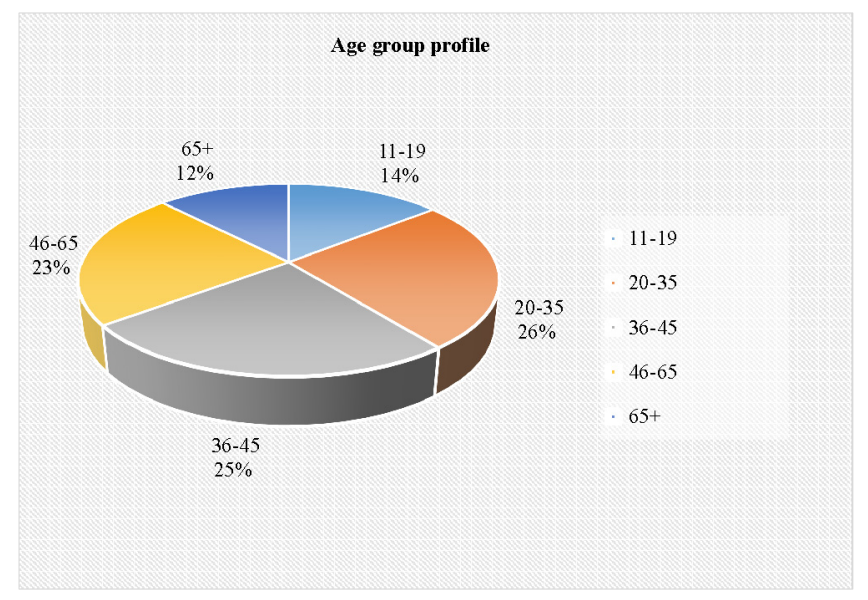

Source: Author's field data, 2019

Figure 8. Age group distribution of the respondents 


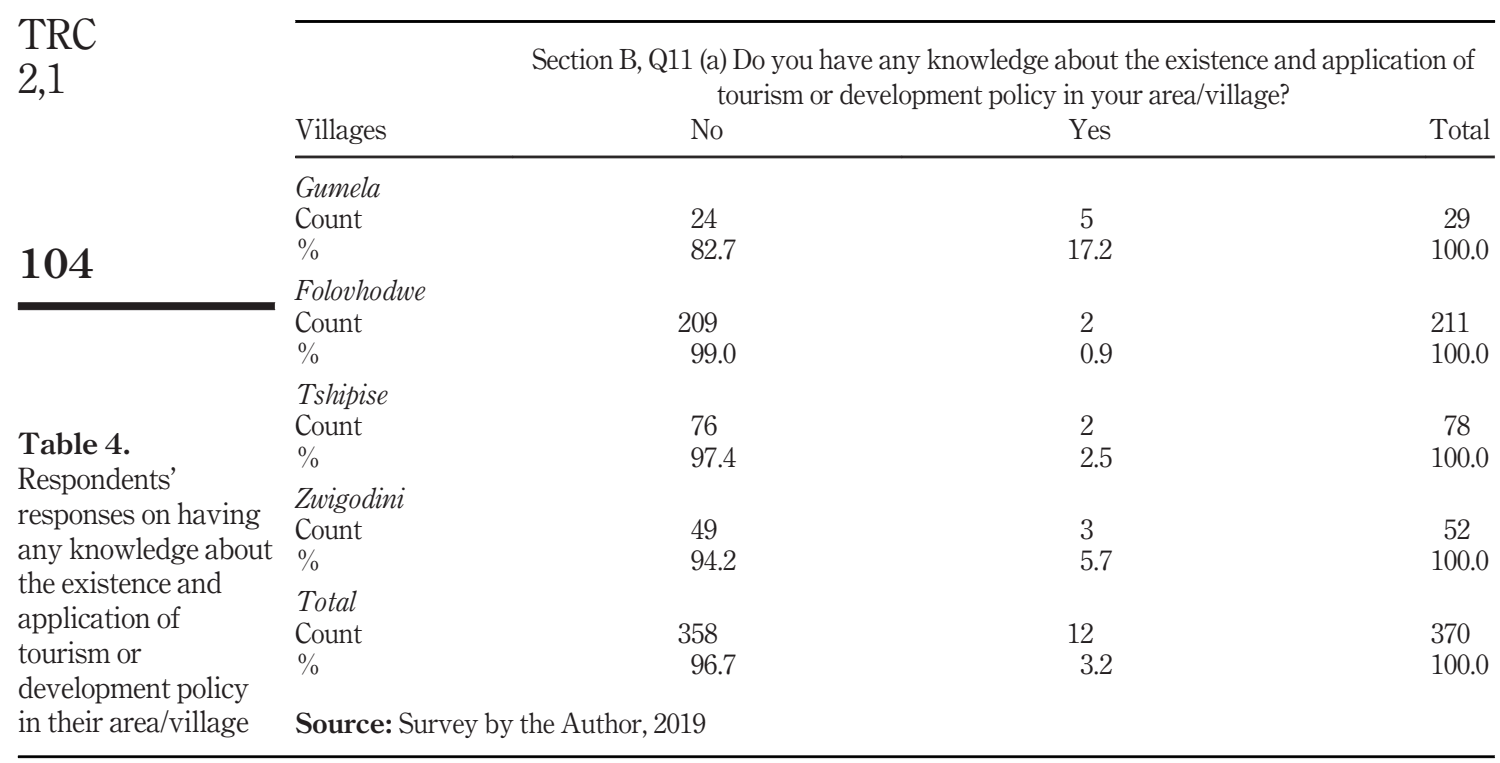

conservation and tourism resources, ultimately enhancing the livelihoods and socioeconomic status of the local community within the area. Furthermore, on the same topic, data also reveal that $83.3 \%$ of the respondents working within tourism ventures and entities agreed that their venture or entity promotes tourism or development policy. The smaller number of $16.6 \%$ of respondents indicated a lack of knowledge about policies and opportunities $(n=30)$ (Key informant interviews within the six sampled tourism ventures and entities 8/9/10 April 2019 [mornings and afternoons]). Any policy that guides tourism development, (or commonly any development), generally requires monitoring of the day-today proceedings of development-related activities to prevent contravention of its ideals; hence, fostering sustainability. A failure to monitor policies is tantamount to a failure of policy to the detriment of local communities and environments - and the apparent gap in perceptions is significant in this study. In this study, $92.5 \%$ of respondents from focus group discussions shared uniform responses on the lack of the enforcement of development or tourism policy in the study area $(n=20)$ (Focus group discussions within all the sampled villages 17/18/19/20 March 2019 [mornings and afternoons]).

These findings are confirmed by a review of secondary documentation and direct observation. These showed a lack of adequate tourism policy application within the study area (Kayamandi Development Services, 2007; Musina Municipality, 2011, 2019; Ramaano, 2019). For example, document review data uncovered weaknesses and inconsistency within the enforcements of tourism development policy and the lack of sufficient promotion and marketing of entities such as Mapungubwe National Park and World Heritage Site, a lack of precise integration and development of new tourism routes, a failure to promote meaningful road improvements on several routes that lead to various tourism destinations and ventures such as the road to "Nwanedi reserve and resort," a lack of a vibrant inclusive tourism strategy based on the endorsement of cultural, indigenous and natural resources; as well as failure to protect and market the recent "Big Tree Nature Reserve" among others in the study area and within the Municipality (Kayamandi Development Services, 2007; Musina 
Municipality, 2011; Ramaano, 2019). In line with the above mentioned, the Municipality has also failed to implement the planned visual enhancement project of baobabs plantations around Musina town and its surrounding peri-urban areas. It is suggested that such planting would represent a remarkable economic and cultural development policy toward branding the Municipality as an astounding tourist destination area. Cleave and Arku (2015) demonstrated how place branding is gaining popularity among municipalities as a policy strategy to lure investments, win over tourists and promote economic development.

Furthermore, Arku et al. (2016) spelled out that public parks not only provide municipalities with recreational and tourism development grounds for local people and tourists but also promote the overall better appearance of a locality, as well as render significant environmental services such as water and air purifications around cities and towns. Hence, Sadler et al. (2016) maintain that the supreme aim of municipalities' place branding is to amplify the economic and social welfare of local dominions. Thus, there is a need for an integrated policy strategy to foster sustainable tourism and community development in the Musina municipality. Therefore, pictures of things such as land fragmentations and destructions of trees species within the Municipal area, inside the nature reserves and on the surrounding communal premises were viewed and also taken by the researcher (See Figure 4 and Figure 3) in an attempt to identify current failings in policy implementation.

\subsection{Sustainable tourism practice and knowledge in the study area}

3.3.1 Respondents' responses on 'village and local communities' adherence to sustainable tourism practices." Data in Table 5 show that a majority of 352 respondents $(95.1 \%)$ denied having any knowledge about their village and local communities adhering to sustainable tourism practices in the study area. Just 18 respondents affirmed the presence of such practices. Suffice to state that sustainable tourism advocates for principles that promote environmental, social and economic ideals (Figure 1). Therefore, it would contribute to the

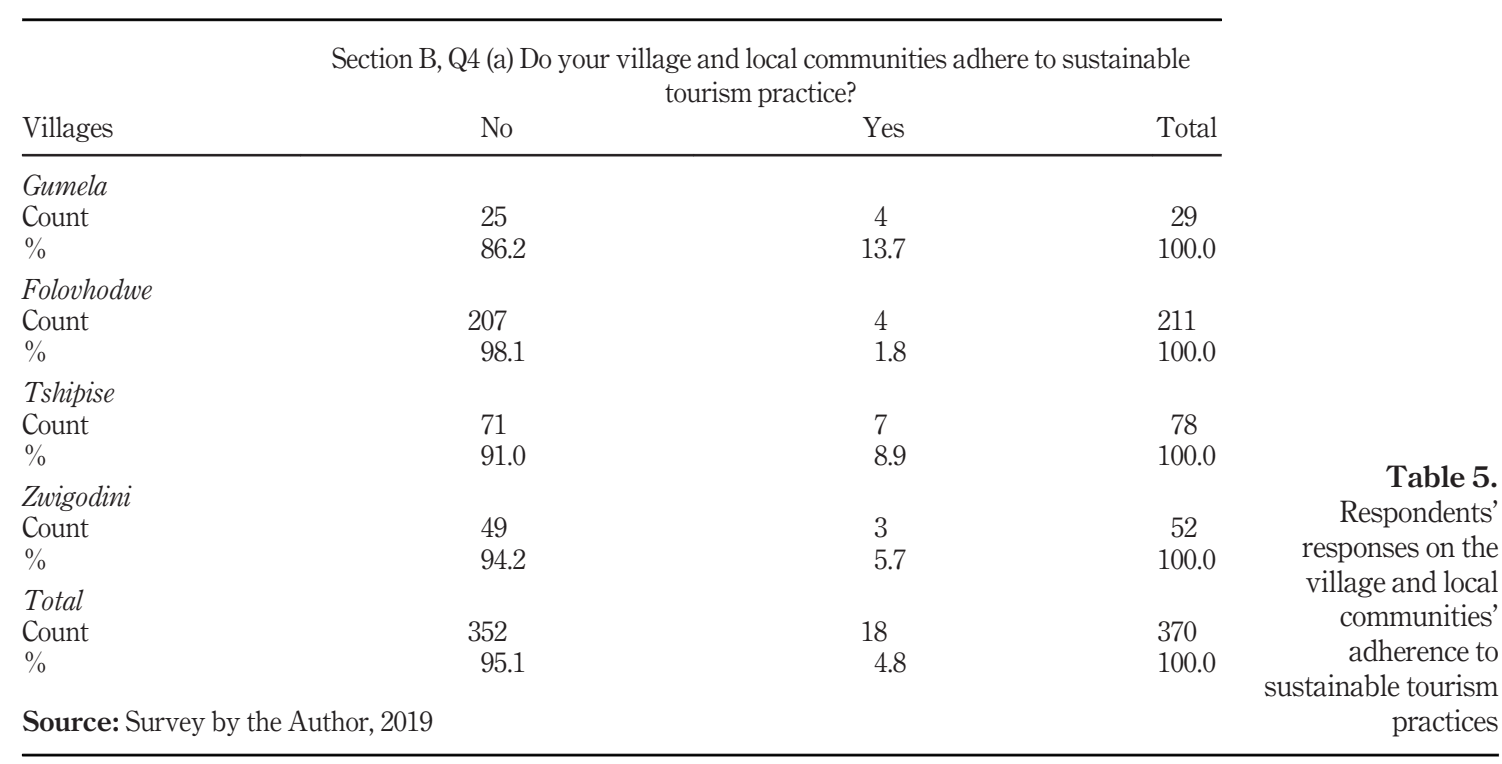


TRC

2,1

106

betterment of the livelihoods of the communities in the study area. Thus, a tourism strategy constructed around sustainable tourism principles and decent tourism policy enforcement will render positive human-environment interaction outcomes for both the development of communities and proper conservation efforts within the study area (Figures 1 and 2).

3.3.2 Respondents' explanations on "how does such activity get to be fulfilled" section B. Q4 (a) (i) Explain how does it/you/they fulfil such activity. While the 18 respondents replied positively about seeing policies supporting sustainable tourism practices in the study area, almost all failed to give any specific examples. They would only mark "yes" but struggled to provide more illustrations or a clear indication thereof. The remainder who tried to offer some elaborated indications provided examples that sounded more playful than the actual meaning of sustainable tourism. The latter was still the case even though the questionnaires were equipped with prior definitions of the respective concepts. The totality of the findings indicated the general lack of decisive knowledge of tourism, environment and sustainability matters and of policies within the study area. On an earlier probe of respondents in the industry, $76.6 \%$ attested to the adherence to sustainable tourism efforts by their ventures and entities, indicating that $23.3 \%$ felt unable to provide specific examples of such policy implementation $(n=30)$ (Key informant interviews within the six sampled tourism ventures and entities 8/9/10 April 2019 [mornings and afternoons]). Sustainable tourism is a supportive pillar of the flourishing tourism industry for it ensures an equitable distribution of conservation, economic and social benefits to its adjacent communities (Ramaano, 2019) (See also Figure 1). Therefore, any prospective scheme that seeks to use tourism as a viable strategy in advancing the community's livelihoods and sustainability achievements should adhere to its sustainable tourism practices and the three significant pillars within tourism policy implementation (See also Figure 2).

3.3.3 Respondents' explanations on "how their tourism ventures and entities adhere to sustainable tourism in the study area" interview.Q4 (a) (i) explain to us how it fulfills such activity. The majority of industry respondents $(23.76 .6 \%)$ were positive about their tourism ventures abiding by sustainable tourism in the study area. Thus, they spelled out that they promote sustainable tourism and environmental conservation education to all their visitors through relevant education materials that help to spread significant information alongside their other hospitality offerings; using things such as web pages, tour guides, coupons and advertisement boards. On the other hand and still, on the same probe, a majority of $90 \%$ of respondents from focus group discussions indicated that they do not wholly abide by sustainable tourism practices within the study area $(n=20)$ (Focus group discussions within all the sampled villages 17/18/19/20 March 2019 [mornings and afternoons]). Physical observation furnished pictures of some of the neglected ecotourism activities (See also Figure 4 and Figure 3).

\subsection{Responsible tourism practice and knowledge in the study area}

3.4.1 Respondents' responses on 'village and local communities' adherence to responsible tourism practices." Data in (Table 6) show that a bulk of 353 respondents indicated there were failures to adhere to sustainable policies, with $95.4 \%$ indicating that such failures existed. Responsible tourism requires everyone to act responsibly when interacting with the natural environment and ensure sustainable utilization of environmental and tourism resources. A sound responsible tourism practice would assure less negative impact on the environment and society, as well as on the economy of the local communities. Suffice to say that sustainable tourism and responsible tourism practices have the same principles and goals, with responsible tourism practice only endorsed to enhance sustainable tourism. 


\begin{tabular}{|c|c|c|c|c|}
\hline \multirow[b]{2}{*}{ Villages } & \multicolumn{3}{|c|}{$\begin{array}{c}\text { Section B, Q5 (a) Do your village and local communities adhere to responsible } \\
\text { tourism practice? }\end{array}$} & \multirow[t]{2}{*}{$\begin{array}{r}\text { Tourism } \\
\text { policy }\end{array}$} \\
\hline & No & Yes & Total & \\
\hline \multicolumn{5}{|l|}{ Gumela } \\
\hline Count & 24 & 5 & 29 & \\
\hline$\%$ & 82.7 & 17.2 & 100.0 & \\
\hline \multicolumn{5}{|l|}{ Folovhodwe } \\
\hline $\begin{array}{l}\text { Count } \\
\%\end{array}$ & $\begin{array}{l}207 \\
98.1\end{array}$ & $\begin{array}{l}4 \\
1.8\end{array}$ & $\begin{array}{l}211 \\
100.0\end{array}$ & \\
\hline \multicolumn{5}{|l|}{ Tshipise } \\
\hline $\begin{array}{l}\text { Count } \\
\%\end{array}$ & $\begin{array}{l}72 \\
92.3\end{array}$ & $\begin{array}{l}6 \\
7.6\end{array}$ & $\begin{array}{c}78 \\
100.0\end{array}$ & \\
\hline $\begin{array}{l}\text { Zwigodini } \\
\text { Count } \\
\%\end{array}$ & $\begin{array}{l}50 \\
96.1\end{array}$ & $\begin{array}{l}2 \\
3.8\end{array}$ & $\begin{array}{c}52 \\
100.0\end{array}$ & $\begin{array}{r}\text { Table 6. } \\
\text { Respondents' } \\
\text { responses on the }\end{array}$ \\
\hline $\begin{array}{l}\text { Total } \\
\text { Count } \\
\%\end{array}$ & $\begin{array}{c}353 \\
95.4\end{array}$ & $\begin{array}{c}17 \\
4.5\end{array}$ & $\begin{array}{l}370 \\
100.0\end{array}$ & $\begin{array}{r}\text { village and local } \\
\text { communities' } \\
\text { adherence to } \\
\text { responsible tourism }\end{array}$ \\
\hline \multicolumn{4}{|c|}{ Source: Survey by the Author, 2019} & practices \\
\hline
\end{tabular}

3.4.2 Respondents' explanations on "how does such activity get to be fulfilled" section B.Q5 (a) (i) Explain how does it/you/they fulfil such activity. Just 17 respondents replied positively about their village and local communities adhering to responsible tourism practices in the study area, but they did not offer clear substantive examples. Most simply expressed support for the notion of responsible tourism principles, but support without dedicated proper preservation actions would mean absolutely nothing significant. A common reason given for such failures was a lack of access to valuable expertise on environmental and responsible tourism issues within the study area and its communities.

3.4.3 Respondents' explanations on "how their tourism ventures and entities adhere to responsible tourism in the study area" interview.Q4 (b) (i) explain to us how it fulfills such activity. Given this, it was not surprising that most actions undertaken in support of sustainable tourism practices tended to exhortations to engage in good practice. Thus, industry respondents primarily spoke of the use of signage boards, brochures and magazines in channeling responsible tourism and sustainable conservation instructions among visitors within and aboard their premises.

\subsection{Other development activities in the study area}

3.5.1 Respondents' responses to other development activities. Data (in Table 7) indicate that an absolute majority of 288 respondents checked "Agriculture" as the other major development activity in their area, while 39 respondents checked "Mining" and 36 respondents ticked "Fishing," while 5 respondents marked "None." Hence, a total of only 2 respondents chose "Others." Therefore, Table 7 depicts three representative categories of responses $-77.8 \%$ for "Agriculture/agroforestry," $10.5 \%$ for "Mining" and finally $9.7 \%$ for "Fishing" ( $n=370)$ (Questionnaire survey within the four sampled villages, distributed between the mornings of 1 March to afternoon 30 April and collected between the mornings of 15 May to afternoon 15 June 2019). "Agriculture and Fishing" are generally among the primary activities practiced by rural communities in remote areas. As such, both agriculture 


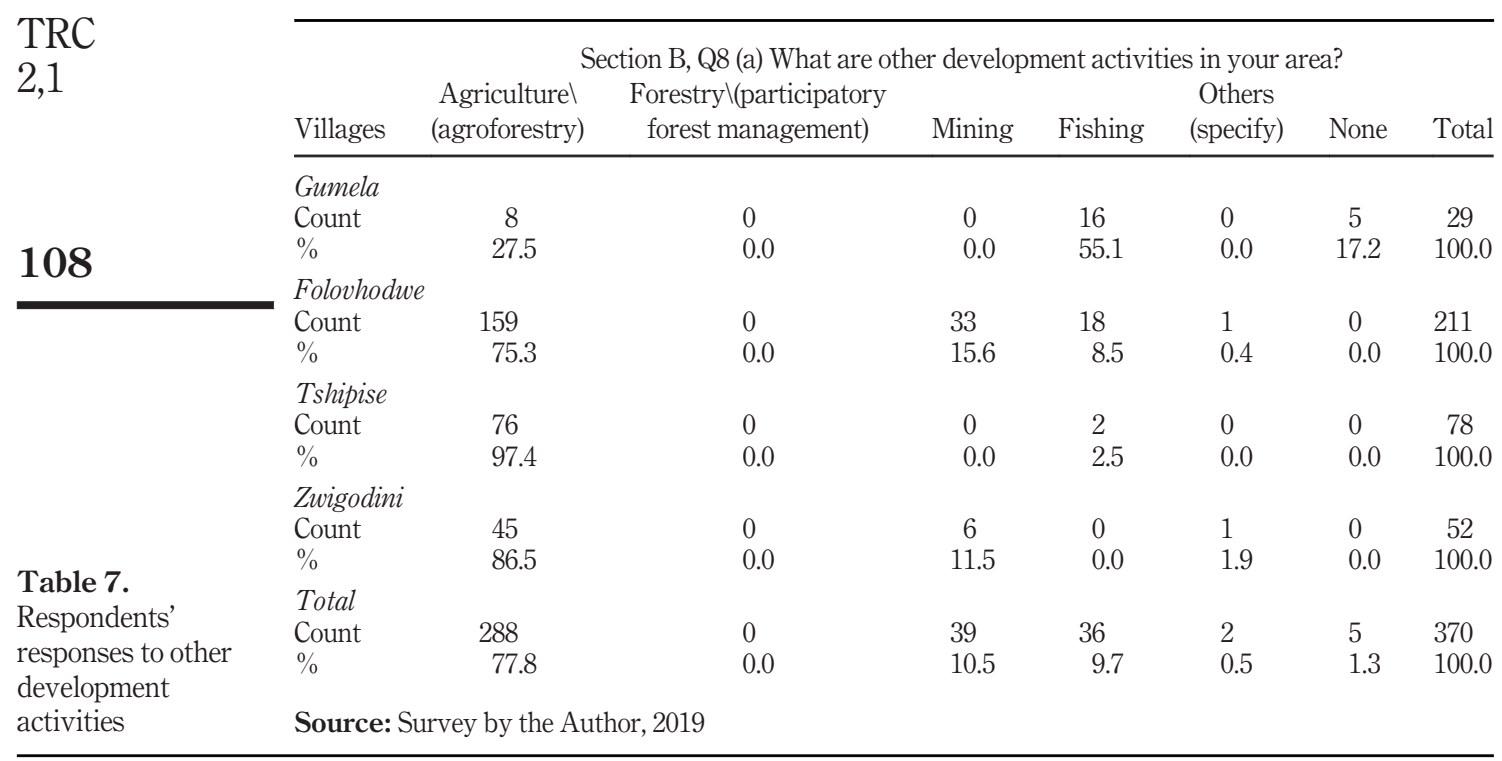

and fishing have always been linked with the smaller-scale generation of income for respective individuals in addition to subsistence practices within the rural communities in the study area (Ramaano, 2019).

There remains the potential of Agri-tourism to generate more income for communities, wherein products are sold locally among the citizens or to tourists. Additionally, on the other hand, both active and abandoned mines have the potential for adventure and heritage tourism. Furthermore, fishing is one recreational and economic activity within the paradigms of both adventure and ecotourism fanatics. In this regard, both fishing and agriculture constitute better platforms for being mixed within a design for potential strategic tourism development and management plan in the study area (Researcher, 2019). These proposals were welcomed by the industry focus group (Focus group discussions within all the sampled villages 17/18/19/20 March 2019 [mornings and afternoons]).

3.5.2 Respondents' responses on "getting any socio-economic benefits from the mentioned development activities." Data in (Table 8) indicates that 85 respondents did not perceive any socio-economic benefits from other major development activities in the study area, while $285(77 \%)$ did so. Agriculture was the most commonly cited example.

Therefore, as the role of agriculture in rural areas is mainly that of subsistence production of food for the families rather than for commercial purposes, it does possess, as noted previously, the potential within a holistic tourism strategy. Such a strategy requires interventions of efficient and integrated development and operational tourism policy in improving the usage of existing activities to obtain community benefits. Again, focus groups responded positively to such suggestions and examples were found of functional agricultural activities in the area, in particular, the Nwanedi irrigation scheme and the adjacent orchards that are fed from a small constructed agricultural dam and the struggling Nwanedi River within and around Folovhodwe village in the study area. 
Section B, Q8 (b) Do you get any socio-economic benefits from the mentioned developments?

\begin{tabular}{|c|c|c|c|c|}
\hline Villages & No & Yes & Total & \\
\hline \multicolumn{5}{|l|}{ Gumela } \\
\hline Count & 16 & 13 & 29 & \\
\hline$\%$ & 55.1 & 44.8 & 100.0 & \\
\hline \multicolumn{5}{|c|}{ Folovhodwe } \\
\hline Count & 31 & 180 & 211 & \\
\hline$\%$ & 14.6 & 85.3 & 100.0 & \\
\hline \multicolumn{5}{|l|}{ Tshipise } \\
\hline Count & 21 & 57 & 78 & \\
\hline$\%$ & 26.9 & 73.0 & 100.0 & \\
\hline \multicolumn{5}{|c|}{ Zwigodini } \\
\hline Count & 17 & 35 & 52 & 1able 8. \\
\hline$\%$ & 32.6 & 67.3 & 100.0 & Respondents \\
\hline \multicolumn{4}{|l|}{ Total } & responses on getting \\
\hline Count & 85 & 285 & 370 & any socio-economic \\
\hline$\%$ & 22.9 & 77.0 & 100.0 & benefits from tl \\
\hline \multicolumn{4}{|c|}{ Source: Survey by the Author, 2019} & developments \\
\hline
\end{tabular}

\begin{tabular}{|c|c|c|c|c|c|c|}
\hline Villages & $\begin{array}{c}\text { Section B, Q 8(b } \\
\text { None } \\
\text { (nothing at all) }\end{array}$ & $\begin{array}{l}\text { How do they con } \\
\text { Insignificantly } \\
\text { (not enough) }\end{array}$ & $\begin{array}{l}\text { ate to your socic } \\
\text { needs? } \\
\text { Significantly } \\
\quad \text { (enough) }\end{array}$ & $\begin{array}{l}\text { nnomic benefits and d } \\
\text { Very significantly } \\
\text { (more than enough) }\end{array}$ & asic & \\
\hline \multicolumn{7}{|l|}{ Gumela } \\
\hline Count & 14 & 15 & 0 & 0 & 29 & \\
\hline$\%$ & 48.2 & 51.7 & 0.0 & 0.0 & 100.0 & \\
\hline \multicolumn{7}{|c|}{ Folovhodwe } \\
\hline Count & 32 & 179 & 0 & 0 & 211 & \\
\hline$\%$ & 15.1 & 84.8 & 0.0 & 0.0 & 100.0 & \\
\hline \multicolumn{7}{|l|}{ Tshipise } \\
\hline Count & 22 & 56 & 0 & 0 & 78 & \\
\hline$\%$ & 28.2 & 71.7 & 0.0 & 0.0 & 100.0 & $\begin{array}{r}\text { Table } 9 . \\
\text { Respondents' }\end{array}$ \\
\hline \multicolumn{5}{|l|}{ Zwigodini } & 52 & responses on "how \\
\hline$\%$ & 30.7 & 69.2 & 0.0 & 0.0 & 100.0 & $\begin{array}{r}\text { are the contribution } \\
\text { of other }\end{array}$ \\
\hline \multirow{2}{*}{$\begin{array}{l}\text { Total } \\
\text { Count } \\
\%\end{array}$} & 84 & 286 & 0 & 0 & 0 & developments to their \\
\hline & 22.7 & 77.2 & 0.0 & 0.0 & 100.0 & $\begin{array}{r}\text { socio-economic } \\
\text { benefits and daily }\end{array}$ \\
\hline \multicolumn{6}{|c|}{ Source: Survey by the Author, 2019} & basic needs" \\
\hline
\end{tabular}

3.5.3 Respondents' responses on "how are the contribution of other developments to their socio-economic benefits and daily basic needs." Data indicated (Table 9) show that a total of 84 respondents replied "none" to socio-economic benefits received from the use of other major development activities in meeting daily basic needs of their living. A majority of 286 
TRC

2,1

110

respondents indicated an insignificant contribution. Hence, it seems that agriculture alone could not offer the best means of helping communities with their basic needs. Again, it is suggested that an integrated development strategy that integrates sustainable tourism with agricultural, mining and fishing activities would create opportunities for the local communities. The document review and physical observation found evidence of several agricultural initiatives, especially within three sampled villages that do not have irrigation or river systems and rely on rainfall. However, given that the Municipality is within one of the hottest and driest settings in the country, there was insufficient rain and irrigation water within the area, meaning that success was not achieved. Views of the abandoned white stone mining and the polluted scenes of the Nwanedi river system within the sampled village of Folovhodwe were also witnessed (Musina municipality, 2019; Ramaano, 2019).

\subsection{Turnaround tourism strategy planned by traditional leaders, local associations and local} communities in the study area

3.6.1 Respondents' responses on "any turnaround strategy planned by their traditional leaders, local associations and local communities for the better management of natural resources and responsible tourism in their area". Data (in Table 10) found that only 13 respondents indicated a positive assessment of the existence of any turnaround strategies orchestrated by traditional leaders, local associations and local communities in their area. Evidence of a perceived failure of an integrated developmental program based on tourism was simply writ large in such responses. Indeed, the 13 who indicated that such responses were made again struggled to provide more detail. There were examples of past plans. For example, in Gumela and Folovhodwe villages, it emerged that partnership changes within the running of the Nwanedi conservation and tourism enterprises were held responsible for the actual worsening of conservation and tourism undertakings. Yet, it seemed little was done with representatives of the local communities and the entities' management to cope

\begin{tabular}{|c|c|c|c|}
\hline \multirow[b]{2}{*}{ Villages } & \multicolumn{3}{|c|}{$\begin{array}{c}\text { Section B, Q7 (a) Is there any turnaround strategy planned by your traditional leaders, } \\
\text { local associations and communities for the better management of natural resources } \\
\text { and responsible tourism in your area? }\end{array}$} \\
\hline & No & Yes & Total \\
\hline \multicolumn{4}{|l|}{ Gumela } \\
\hline Count & 25 & 4 & 29 \\
\hline$\%$ & 86.2 & 13.7 & 100.0 \\
\hline \multicolumn{4}{|c|}{ Folovhodwe } \\
\hline Count & 207 & 4 & 211 \\
\hline$\%$ & 98.1 & 1.8 & 100.0 \\
\hline \multicolumn{4}{|l|}{ Tshipise } \\
\hline Count & 76 & 2 & 78 \\
\hline$\%$ & 97.4 & 2.5 & 100.0 \\
\hline \multicolumn{4}{|l|}{ Zwigodini } \\
\hline Count & 49 & 3 & 52 \\
\hline$\%$ & 94.2 & 5.7 & 100.0 \\
\hline \multicolumn{4}{|l|}{ Total } \\
\hline Count & 357 & 13 & 370 \\
\hline$\%$ & 96.4 & 3.5 & 100.0 \\
\hline
\end{tabular}

Table 10.

Respondents' responses on any turnaround strategy planned by their traditional leaders, local associations and local communities for the better management of natural resources and responsible tourism in their area

ee: Survey by the Author, 2019 
with the worsening situation. In Zwigodini and Madifha villages informants stated that there have been many meetings about the obligations to preserve the big "Baobab" tree because the tree is vulnerable to ill-treatment by both locals and visitors. The latter was associated with the fact that the visitors are scrapping the tree to mark their specific days of visits (Figure 3). Thus, the "Tree" has, up to this point, not been sufficiently protected and the Reserve itself seems to be not well handled and supervised (See Figure 4). Also, with Tshipise' Sagole Spa, it stood out that there seemed to be frequent misappropriations of funds aimed at developing a "Trust" to revive and refurbish the Sagole Spa tourism hub by the higher chief of the area without any formal investigations or disciplinary consequences. These were some of the issues aired during focus discussions. The questionnaire also revealed past visits by delegates from the Musina municipality local economic development "LED" section, with the objective of "getting to the root of the problem," but the evidence indicated that at the time of the research little had been achieved.

\section{Conclusions}

The study first looked at the demographic profiles of the respondents with tourism and communities' livelihoods in the study area. More specifically, the study evaluated the nature of tourism and development policies, its environmental sustainability and the existence of any other major development activities in the study area. The study also attempted to evaluate the behavior and attitude of the local communities toward tourism initiatives and environmental matters and the potential significance of sustainable tourism principles in improving their livelihoods within the area. It was found that there was poor enforcement of tourism development policy and the communities' knowledge about policies and opportunities was generally below par within the study area. The situation was exacerbated by deficiencies surrounding any tourism strategy to address issues, identify opportunities or better inform local communities. Put simply, it was clear from the data that tourism is not currently promoted and or practiced in an environmentally sustainable manner within the area.

Yet, on the other hand, according to Ramaano (2019), the study area is enriched with wonderful tourism potential; and a feeling that a combination of local communities, government and non-governmental organizations dealing with rural and sustainable tourism possesses a potential for future improved tourism undertakings. As McIntyre et al. (1993) indicated, communities should sustain themselves through local, provincial and national development endeavors and adequately associate themselves with government and other role-players at every turn. Moreover, Ryan (2020) elaborates that tourism destinations consist of an array of attractions, various types of accommodations and services. Hence, joint public-private sector ownerships or governed associations are familiar and could be applied. Any strategy will have to rely on the abundance of cultural heritage and indigenous resources, as well as the overall biodiversity in the study area (Ramaano, 2019).

This study has also concluded that, contrary to the common attitude that rural areas are often too distant and too resource deficient to permit tourism development, such areas are often a better choice for tourism possessing adventure, cultural, ethnic and ecotourism opportunities. However, these opportunities require integrated developmental policies, properly implemented to make the most of these potential synergies. Ramaano (2019) has suggested that rural areas can tap into significant indigenous species (such as "Baobabs" [Adansonia digitata], Marulas [Sclerocarya birrea], Mopani [Colophospermum mopane] and Aloe Vera [Aloe barbadensis miller] in the case of the study area) and integrate these into sustainable tourism and local community economic. For example, edible worms (Gonimbrasia belina) from Mopani trees can be incorporated into a bonafide enterprise. 
TRC

2,1

112

Moreover, Ramaano (2019) revealed the abundance of cultural resources such as arts, crafts and cultural dances as the renowned "Tshikona" dance among others in the study area. These aspects of culture can be merged within the heritage, cultural and agro-tourism initiatives that can benefit community development strategies. Just as Dieke (1993, 2003) found concerning tourism policy, employment and development in The Gambia and African context in general, this study has revealed akin lacks in terms of authorities and communities' expert knowledge in the tourism development policy, sustainable tourism and environmental sustainability within the study area. Even though the findings from this study could not, in themselves, formulate a final tourism strategy to develop a tourism policy and consistent with best environmental practice in Musina local municipality, it has raised awareness of potentialities and offered practices that can supplement agriculture initiatives derived from land reform (Govender-Van Wyk, 2007; Ramaano, 2019).

In conclusion, the study highlights several deficiencies of policy and practice in the Musina local municipality. It argues for a more integrated approach to tourism in ways thought to benefit residents in the local communities. Joshi and Dhyani (2009) argued that environmental charge fees could positively reduce abuse borne by tourism activities in a sensitive environment. The implementation of such fees could prove beneficial for avoiding further abuse of the "big baobab tree" within the Big Tree Nature Reserve and possibly many other similar scenarios within the areas' ecotourism resources.

Studies of tourism failure are rare in the tourism literature, and thus this study contributes to that literature. However, additionally, a study of failure can emphasize the potential of "policies have done right." As its limitation, the study predominately settled for Microsoft excel and cross-tabulation analysis, in the absence of any other data analysis techniques. However, this did not compromise the credibility of the study's findings. Hence, (Figure 1) represent principles of sustainable tourism, adopted from White et al. (2006) and Zamfir et al. (2017) of which the study area communities should liaise with and be encouraged by its values; whereas (Figure 2) represent the ideated model and theme of sustainable tourism and sustainable community livelihoods for the study. Therefore, the study contends for sound adherence to sustainable tourism paragons in the study area, as manifested in (Figures 1 and 2). The next part presents references for the study.

\section{References}

Arku, G., Yeboah, I.E. and Nyantakyi-Frimpong, H. (2016), "Public parks as an element of urban planning: a missing piece in Accra's growth and development", Local Environment, Vol. 21 No. 12, pp. 1500-1515.

Baobab Travel (2015), available at: www.baobabtravel.com/about/who-we-are/ (accessed 7 June 2018).

Cleave, E. and Arku, G. (2015), "Place branding and economic development at the local level in Ontario, Canada”, Geo Journal, Vol. 80 No. 3, pp. 323-338.

Crouch, N.R., Douwes, E., Wolfson, M.M., Smith, G.F. and Edwards, T.J. (2008), "South Africa's bioprospecting, access, and benefit-sharing legislation: current realities, future complications, and a proposed alternative", South African Journal of Science, Vol. 104 Nos 9/10, pp. 355-366.

Davis, B. (1995), Vanishing Waters, Clyson printers, Cape Town.

De Araujo Lima Constantino, P., Carlos, H.S.A., Ramalho, E.E., Rostant, L., Marinelli, C.E., Teles, D., Fonseca-Junior, S.F., Fernandes, R.B. and Valsecchi, J. (2012), "Empowering local people through community-based resource monitoring: a comparison of Brazil and Namibia”, Ecology and Society, Vol. 17 No. 4.

De Araujo, L.M. and Dredge, D. (2012), “Tourism development, policy and planning in Brazil”, Tourism in Brazil: Environment, Management and Segments, Routledge, New York, NY, pp. 17-29. 
Dieke, P.U. (1993), "Tourism and development policy in the Gambia”, Annals of Tourism Research, Vol. 20 No. 3, pp. 423-449.

Dieke, P.U. (2003), "Tourism in Africa's economic development: policy implications", Management Decision, Vol. 41 No. 3.

Dillon, C. and Murphy, C.B. (2008), Interviewing in Action in a Multicultural World, Thomson, Belmont, CA.

DuFour, R. and Eaker, R. (2009), On Common Ground: The Power of Professional Learning Communities, Solution Tree Press.

Ekanyake, E.M. and Long, A.E. (2012), "Tourism development and economic growth in developing countries", The International Journal of Business and Finance Research, Vol. 6 No. 1, pp. 51-63.

Esterberg, K.G. (2002), Qualitative Method in Social Research, McGraw-Hill, Boston.

Glazewski, I.N. (2005), Environmental Law in South Africa, 2nd ed., Butter Worth. S. A, Cape Town, LexisNexis.

Govender-Van Wyk, S. (2007), Community-Based Sustainable Tourism on Commonages: An Alternative to Traditional Land Reform in Namaqualand, Northern Cape Province, University of Pretoria etd.

Jones, A. (1993), "Sustainability and community participation in rural tourism", Leisure Studies, Vol. 12 No. 2, pp. 147-148.

Joshi, R. and Dhyani, P.P. (2009), "Environmental sustainability and tourism-implications of trend synergies of tourism in Sikkim Himalaya", Current Science, pp. 33-41.

Judd, E.R. (2002), The Chinese Women's Movement between State and Market, Stanford University Press.

Kayamandi development services (2007), LED Strategy Chapter 4, Musina local municipality.

Kepe, T. (2004), "Decentralisation when land and resource rights are deeply contested: a case study of the Mkambati eco-tourism project on the Wild Coast of South Africa", European Journal of Development Research, Vol. 25 No. 1, p. 71.

Keyser, H. (2002), Tourism Development, Oxford University Press, Southern Africa (Pty), Cape Town.

Kirsten and Rogerson (2002), Ecotourism Development: Development Southern Africa Journal, Kirsten and Rogerson, Vol. 22.

Lea, J. (1988), Tourism and Development in the Third World, Routledge, London.

Lohmann, G. and Dredge, D. (2012), Tourism in Brazil: Environment, Management and Segments, Routledge.

McIntyre, G., Hetherington, A. and Inskeep, E. (1993), Sustainable Tourism Development: Guide for Local Planners, World Tourism Organisation, Madrid.

Maikhuri, R.K., Negi, V., Rawat, L.S. and Purohit, V.K. (2007), Promoting Value Addition in Potential Wild Edibles of Central Himalaya for Sustainable Livelihood and Small Scale Enterprise Development, GB Pant Institute of Himalayan Environment and Development.

Martín, J.M.M., Aguilera, J.D.D.J. and Moreno, V.M. (2014), “Impacts of seasonality on environmental sustainability in the tourism sector based on destination type: an application to Spain's Andalusia region”, Tourism Economics, Vol. 20 No. 1, pp. 123-142.

Musina municipality (2011), Limpopo Provincial Government, IDP.

Musina municipality (2019), Limpopo Provincial Government, IDP.

Nanthakumar, L., Ibrahim, Y. and Harun, M. (2007), Tourism Development Policy, Strategic Alliances and Impact of Consumer Price Index on Tourist Arrivals: The Case of Malaysia, TOURISMOS.

National Department of Tourism (2012), South Africa.

National Geographic Expeditions (2015), "National geographic expeditions", available at: www. nationalgeographicexpeditions.com/ (accessed 11 September 2017). 
TRC

2,1

114

Patton, M.Q. (2001), Qualitative Research and Evaluation Methods, 2nd ed., Sage Publications, Thousand Oaks, CA.

Ramaano, A.I. (2019), The Prospects of Using Tourism Industry to Advance Community Livelihoods in Musina Municipality, Limpopo, South Africa, University of Venda.

Ryan, C. (2002), "Equity, management, power sharing and sustainability - issues of the "new tourism", Tourism Management, Vol. 23 No. 1, pp. 17-26.

Ryan, C. (2005), "Who manages indigenous cultural tourism product - aspiration and legitimization?", Indigenous Tourism, Elsevier, pp. 69-73.

Ryan, C. (2020), Advanced Introduction to Tourism Destination Management, Edward Elgar Publishing.

Ryan, C. and Page, S. (2012), Tourism Management, Routledge.

Sadler, R., Cleave, E., Arku, G. and Gilliland, J. (2016), "A comparative analysis of place branding in Michigan and Ontario", Urban Research and Practice, Vol. 9 No. 1, pp. 16-36.

Tongco, M.D.C. (2007), "Purposive sampling as a tool for informant selection", Ethnobotany Research and Applications, Vol. 5, pp. 147-158.

White, V., McCrum, G., Blackstock, K.L. and Scott, A. (2006), Indicators and Sustainable Tourism: Literature Review, The Macaulay Institute, Aberdeen.

Wickens, E. and Briedenhann, J. (2004), "Tourism routes as a tool for economic development of rural areas vibrant hope or impossible dream?", Tourism Management, Vol. 25 No. 1, p. 71.

Witt, S.F. and Witt, C.A. (1995), "Forecasting tourism demand: a review of empirical research", International Journal of Forecasting, Vol. 11 No. 3, pp. 447-475.

Yamane, T. (1967), "Statistics: an introductory analysis", (No. HA29 Y2 1967).

Yamane, T. (1973), Statistics: An Introductory Analysis, Harper and Row, New York, NY.

Zamfir, A., Popa, I., Cicea, C., Dobrin, C. and Marinescu, C. (2017), New Experiences for International University Cooperation in Economic Education and Research in Romania, The Bucharest University of Economic Studies, pp. 1392-1400, doi: 10.21125/inted.2017.046.

\section{Further reading}

Government of Republic of South Africa (1996), Growth, Employment and Redistribution: A Macroeconomic Strategy (GEAR), Ministry of Finance, Pretoria.

\section{Corresponding author}

Azwindini Isaac Ramaano can be contacted at: azwira@webmail.co.za

For instructions on how to order reprints of this article, please visit our website: 